\title{
Study of Carrying Capacity Assesment for Natural Fisheries in Jatibarang Reservoir In Semarang City
}

\author{
Bambang Sujono ${ }^{1}$, and Sutrisno Anggoro ${ }^{2}$ \\ ${ }^{1}$ Master Program of Environmental Science, School of Postgraduate Studies, Diponegoro University, Semarang - Indonesia. \\ ${ }^{2}$ Fisheries and Marine Sciences, Diponegoro University, Semarang - Indonesia
}

\begin{abstract}
Jatibarang reservoir serves as water supply in dry season and controlling flood in Semarang City. This reservoir is stem Kreo River which cathment areas of $54 \mathrm{~km}^{2}$, pool of area 110 ha and volume is 20 billion $\mathrm{m} 3$. This reservoir is potential to develop as natural fisheries area. The goals of this research were to explore existing condition of physical, bio logical as well as chemical parameter; carrying capacity assessment for natural fisheries; determining appropriate fish species to be developed in Jatibarang reservoir. This research was done in descriptive explorative scheme. Field survey and laboratory analyses were conducted to identify physical, chemical and biological parameters of the water. Physical parameters measured were temperature and water brightness. Chemical parameters measured were $\mathrm{pH}, \mathrm{DO}$, phosphate, Ammonia, nitrites and nitrate, while biological parameter measured were chlorophyll-a concentration. Carrying capacity analyses was done referred to the Government Regulation Number 82, 2001 that regulate the management of water quality and water pollution control. Based on the research, it showed that the existing condition of physical, chemical and biological parameters were still good to be used for natural fisheries. Based on TSI index, it classified as eutrofic water. Furthermore, tilapia fish (Oreochromis mossambicus), nile tilapia (Oreochromis niloticus) tawes (Barbonymus gonionotus) and carper fish (Cyprinus carpio) were considered as best species for natural fisheries in Jatibarang Reservoir.
\end{abstract}

\section{Introduction}

Jatibarang reservoir that is built in Kandri Village, Gunung Pati sub-district, Semarang city is strategic area of environmental support, with the major function as flood controller and can be develop as tourism. Reservoir of Jatibarang serves as water storage in the dry season and controlling flood during rainy season. This reservoir was stemming Kreo River which catchment areas is $54 \mathrm{~km}^{2}$, broad puddle 189 ha and reservoir volume is 20,4 millionm $^{3}$ [1]. The such condition has a chance to develop as natural fisheries.

\section{Material and methods}

This Research location was Jatibarang Reservoir, Semarang City, Central Jawa. The research was divide into two activities, field survey and laboratory analyses. Primary and secondary data was collected during field survey and water quality analyses was conducted in Laboratory of Fisheries Department, Diponegoro University, Semarang City. Water sampling was done during February, 2017 in 4 location (Figure 1). Physical parameters measured were water temperature, water brightness; Chemical parameters measured were $\mathrm{pH}$, DO, Phosphate, Ammonia, Nitrite, and nitrate. Furthermore biological parameters measured were chlorophyll-a concentration.

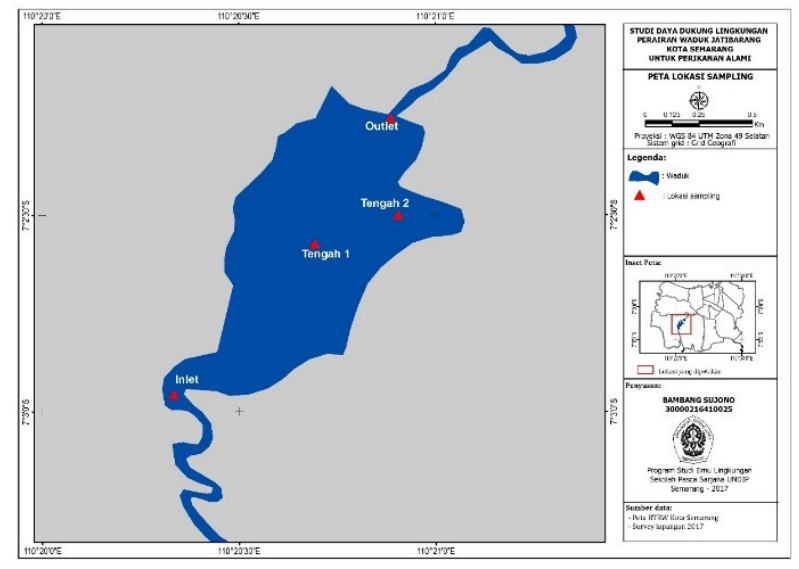

Fig. 1.Sampling Location in Jatibarang Reservoir

Corresponding author: abee4833@gmail.com 
Water sampling were done in the surface water in inlet, two location in reservoir water body dan one location in outlet.

Physical, chemical and biological analyses were conducted in laboratory. (Table 1).

Table 1.Water Quality Analyses Methods

\begin{tabular}{|c|c|c|c|}
\hline Parameter & unit & Methods/tool & Description \\
\hline \multicolumn{4}{|l|}{ Physical } \\
\hline Temperature & & Thermo meter & In-situ \\
\hline Brightness & $\mathrm{cm}$ & Visual, Secchi disk & In-situ \\
\hline \multicolumn{4}{|l|}{ Chemical } \\
\hline $\mathrm{pH}$ & - & $\mathrm{pH}$ meter & In-situ \\
\hline DO & $\mathrm{mg} / \mathrm{L}$ & DOmeter & In-situ \\
\hline Ortofosfat & $\mathrm{mg} / \mathrm{L}$ & Spektrofotometer & Ex-situ \\
\hline Total Fospat & $\mathrm{mg} / \mathrm{L}$ & $\begin{array}{l}\text { Molybdate ascorbic } \\
\text { Acid, Spektrofotometer }\end{array}$ & Ex-situ \\
\hline Amonia & $\mathrm{mg} / \mathrm{L}$ & $\begin{array}{l}\text { Phenate, } \\
\text { Spektrofotometer }\end{array}$ & Ex-situ \\
\hline Nitrit & $\mathrm{mg} / \mathrm{L}$ & $\begin{array}{l}\text { Sulfanilamide, } \\
\text { Spektrofotometer }\end{array}$ & Ex-situ \\
\hline Nitrat & $\mathrm{mg} / \mathrm{L}$ & $\begin{array}{l}\text { Brucine, } \\
\text { Spektrofotometer }\end{array}$ & Ex-situ \\
\hline \multicolumn{4}{|l|}{ Biologycal } \\
\hline Chlorophyll-a & $\mathrm{mg} / \mathrm{m}^{3}$ & Spektofotometer & Ex-situ \\
\hline
\end{tabular}

Series of analyses was done including physical, chemical and biological parameters to describes water fertilities and the status of carrying capacity of natural fisheries[2] Tropic State Index (TSI) was applied to determine water fertilities [3], which mainly using three parameters (water brightness, phosphate total and chlorophyll-a).

TSI-P $=14,42 \times \operatorname{Ln}[\mathrm{TP}]+4,15(\mu \mathrm{g} / \mathrm{l}) \ldots . .(\mathrm{i})$

TSI-Cla $=30,6+9,81 \times \mathrm{Ln}[$ Chlor-a] $(\mu \mathrm{g} / \mathrm{l}) . .(\mathrm{ii})$

TSI-SD $=60-14,41 \times \mathrm{Ln}[$ Secchi] (meter) ..(iii)

TS I Average $=($ TSI-P + TSI-Cla + TSI-SD)/3..(iv)

Which:

TSI-P is Trophic State Indek for phospat

TSI-Cla is Trophic State Indek for chlorophyll-a

TSI- SD is Trophic State Indek for secchi disk depth

Based on TSI index, level of water fertilities wereultra oligotrophic $(<30)$, oligotrophic (30-40), mesotrophic (40-50), eutrophic (50-60), weight eutrophic (60-70), hipereutrohic (70-80) and alga scum (>80)(Carlson,1977).

Fish production and carrying capacity for natural fisheries fully depends on plankton production. Therefore natural fisheries carrying capacity was analysed using plankton primary productivity.
Primary production productivity was common method to predict fish production and ranching. Primary productivity $\left(\sum \mathrm{PP}\right)$ calculated by maximum chlorophyll a concentration [4].

Based on TSI and chlorophyll concentration, stated that chlorophyll concentration in eutrofic condition is 20 $\mathrm{mg} / \mathrm{m}^{3}[3]$. Chlorophyll a concentration used to predict primary productivity based on [5].

$$
\sum \operatorname{PP}=\frac{483 * \text { Chla }^{1,33}}{9+1,15^{*} \text { Chla }^{1,33}}
$$

Primary productivity was conversed to calculated annual fish production based on conversion table [6] below:

\begin{tabular}{|c|c|c|}
\hline & PP & Annual fish production \\
\hline \multicolumn{2}{|c|}{ (gC/m²/year) } & (g fish $\mathrm{C} / \mathrm{m}^{2} /$ year) \\
\hline \multicolumn{2}{|c|}{$<1000$} & $1,0-1,2$ \\
\hline 1000 & -1500 & $1,2-1,5$ \\
\hline 2000 & -2500 & $\begin{array}{ll}2,1 & -3,2\end{array}$ \\
\hline 2500 & -3000 & $\begin{array}{ll}3,2 & -2,1\end{array}$ \\
\hline 3000 & -3500 & $\begin{array}{ll}2,1 & -1,5\end{array}$ \\
\hline 3500 & -4000 & $1,5-1,2$ \\
\hline
\end{tabular}

Table 2. Annual Primary Productivity Conversion based on Beveridge, 1984

Furthermore, fish species analyses was done using catched fish during field survey in Jatibarang reservoir.

\section{Results and discussion}

\subsection{The condition of Jatibarang reservoir}

Geographically, Jatibarang reservoir was located in coordinate $110^{\circ} 20^{\prime} 49.71$ "E and $7^{\circ} 2^{\prime} 24.67^{\prime \prime S}$. Based on administrative located in Kandri Village, Gunung Pati Sub district, Semarang City (Figure 2). This reservoir was stemming Kreo River which catchment area 54 $\mathrm{km}^{2}$, broad puddle 184 ha and reservoir volume is 20 $\mathrm{m}^{3}$, and 10-15 meter in depth. This reservoir was supply water for West Semarang District which debit is 1.050 $\mathrm{lt} / \mathrm{second}$, maximum water level is $+155.30 \mathrm{~m}$, level above foundation $74 \mathrm{~m}$ and peak elevation $+157 \mathrm{~m}, 200$ $\mathrm{m}$ peak length. 


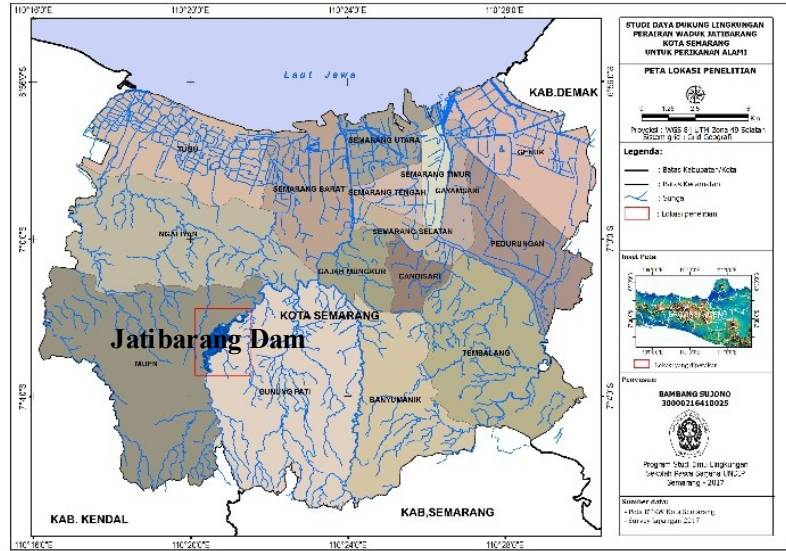

Fig. 2.Map Of Jatibarang Reservoir

\subsection{Physical, Chemical and Biological Parameters}

The results of in situ and ex situ parameters were as shown in Table 3 below.

Table3.Physical, Chemical and Biological Parameters of Jatibarang Reservoir.

\begin{tabular}{|l|c|c|c|c|c|}
\hline Parameter & Unit & St 1 & St 2 & St 3 & St 4 \\
\hline Temperature & ${ }^{0} \mathrm{C}$ & 29.5 & 30,3 & 30.8 & 30,9 \\
\hline $\mathrm{pH}$ & - & 6.9 & 7.1 & 7.2 & 7.1 \\
\hline $\mathrm{DO}$ & $\mathrm{mg} / \mathrm{L}$ & 4,90 & 5,00 & 5,10 & 5,10 \\
\hline Brightness & $\mathrm{M}$ & 0,80 & 1.45 & 1.6 & 1,20 \\
\hline Nitrat & $\mathrm{mg} / \mathrm{L}$ & 1,21 & 0,91 & 1,19 & 0,79 \\
\hline Nitrit & $\mathrm{mg} / \mathrm{L}$ & 0,06 & 0,05 & 0,06 & 0,04 \\
\hline Amonia & $\mathrm{mg} / \mathrm{L}$ & 0,08 & 0,05 & 0,04 & 0,20 \\
\hline Ortofosfat & $\mathrm{mg} / \mathrm{L}$ & 0,06 & 0,07 & 0,07 & 0,06 \\
\hline Total Fosfat & $\mathrm{mg} / \mathrm{L}$ & 0,53 & 0,31 & 0,15 & 0,16 \\
\hline Chlorophyll-a & $\mathrm{mg} / \mathrm{m}^{3}$ & 55,15 & 70,45 & 60,31 & 35,12 \\
\hline
\end{tabular}

The physical, chemical and biological parameters of Jatibarang reservoir was various during the research (Table 3). Water temperature range was $29,5-30,9^{\circ} \mathrm{C}$ which average $30,37^{\circ} \mathrm{C}$. Optimum temperature for trophical fish is $25-32^{\circ} \mathrm{C}$ [7]. Water brightness range 0,8 - 1,6 $\mathrm{m}$ which average 1,26 m. Lowest water brightness located in inlet area in correlation with concentration of total dissolved suspend. The level of water brightness describe euphotic zone indirectly, it correspond to nutrient concentration in water body [2]. $\mathrm{pH}$ range was netral 6.9-7.1 which average 7.05. Mostly aquatic species sensitive with $\mathrm{pH}$ dan prefer in range $7-8,5$ [8]. Dissolved oksigen range 4.9-5.1 mg/l which average $5,06 \mathrm{mg} / \mathrm{l}$. Commonly DO concentration $5 \mathrm{ppm}$ which water temperature $20-30^{\circ} \mathrm{C}$ suitable for fish [9].

Dissolved oxygen parameter is vital parameter for the water organism. DO concentration tends to the weather. The oxygen levels have an real to water living [10]. Oxygen plays an important role as an indicator of the quality of waters, because oxygen dissolved participate in the process oxidation and reduction of organic matter and inorganic. In addition, oxygen also determines biological done by an organism aerobic or anaerobic .The aerobics, the role of oxygen is to oxidize organic matter and inorganic with the end result is nutrients which in turn would give fertility [11]. The main source of oxygen dissolved my water is diffusion from the air and results photosynthesis organisms have chlorophyll living in waters. Diffusion of oxygen from the air into the water was very slow, therefore phytoplankton is the main source of dissolved oxygen in the water (Moriber, 1974) [10].

Fishes use oxygen to their activities, growth , reproduction etc. Hence oxygen for fish determine a circle of fish activities, feed conversion. Growth rete similarly depend on oxygen with the provisions of another factors is optimum [12].

The nitrites concentration between $0.04--0,06 \mathrm{mg} /$ 1 with average of $0.05 \mathrm{mg} / 1$. Concentration of ammonia $0,02-0,8$ with an average $0,092 \mathrm{mg} / \mathrm{l}$, is still in range within the limits of tolerance for life fish. Pescod (1973 ) and samuel et. al. described it on tropical waters no more than $1.0 \mathrm{mg} / \mathrm{l}$ for fisheries. The concentration of orthophosphate $0,06-0,07 \mathrm{mg} / \mathrm{l}$ with an average 0,067 $\mathrm{mg} / \mathrm{l}$, meanwhile the total phosphorus range $0,15-0,63$ $\mathrm{mg} / \mathrm{l}$ with an average $0,28 \mathrm{mg} / \mathrm{l}$.

\subsection{Carrying capacity for natural fisheries}

Carrying Capacity is sum or quantity maximum a fish that can supported by a body of water in the long time, influenced by time laundering, volume of water body, and load waste in to the waters. Natural fisheries in reservoir are herbivorous and fully utilizing phytoplankton in waters as a source of nutrients.

The basic principle of natural fisheries is based on the capacity of waters which includes the condition of physics, chemical and biological waters. This is because natural fisheries fully rely on natural food chain and to avoid any chemicals derived from the rest of artificial feed.

Based on field survey and laboratory analyses, the physical, chemical and biological parameters in Jatibarang reservoir still in good condition for natural fisheries activities based on level 3 standart on Government Regulation Number 82, 2001 concerning in water quality dan water pollution control [13].

Meanwhile TSI index range between 60-65, therefore Jatibarang Reservoir indicated medium eutrophic. It's indicates that productivity of waters high with the low diversity. Based on it, it is highly recommended that natural fisheries to be developed.

The most fish catched during the research were tilapia fish (Oreochromis mossambicus) and nile tilapia (Oreochromis niloticus). This two species were mostly recommend as fish species for natural fisheries in Jatibarang reservoir in Semarang City. 


\section{Conclusion}

Based on this research, can be concludes :

a. Existing condition of chemical and biological parameters of Jatibarang reservoir is still good for natural fisheries based on level 3 Government Regulation Number 82, 2001 that regulate the management of water quality and water pollution control.

b. Carrying capacity of Jatibarang Reservoir based on TSI Index was 60-65, therefore called medium eutrophic. It showed that water productivities is high and low in diversity.

c. Tilapia fish (Oreochromis mossambicus), nile tilapia (Oreochromis niloticus), tawes (Barbonymus gonionotus) and carper fish (Cyprinus carpio) were recommended species for natural fisheries in Jatibarang reservoir.

\section{References}

1. Wening Indriani, Sahala Hutabarat, Churun A'in. Diponegoro Journal of Maquares 5(4): 258264.(2016)

2. Pratiwi, T.MNiken,S, Hariyadi, Inna Puspa Ayu, Novita MZ, Tri Apriadi, Jurnal Biologi Indonesia 11(2):267-274. (2015)

3. R. E. Carlson, A trophic State Index for Lakes. Limnology and Oceanography 22 (2): 361369.(1977)

4. De Silve SS, Amarasinghe US, Nguyen TTT. Better practice approaches for culture based fisheries development in Asia. ACIAR Monograph 120 (2006)

5. Smith VH, Journal of Plankton Research 29 (1): 1-6. (2007)

6. Beveridge MCM. Cage and pen fish farming: carrying capacity model and environmental impact. FAO. Fisheries Technology Paper (255): 131 p. (1984)

7. Mulyanto. Lingkungan Hidup Untuk Ikan. Departemen Pendidikan dan Kebudayaan, Jakarta. (1992)

8. V. Novotny, and H. Olem, Water Quality: Prevention, Identification and Management of Diffuse Pollution. Van Nostrand Reinhold. New York. 1054 p. (1994)

9. Rifa'I RS, Pertagunawan K. Biologi Perikanan 1. Penerbit CV Kayago, Jakarta (ID). (1983)

10. Edward and MSTarigan, Makara Sains 7,(2),8289(2003)

11. Salmin, Oksigen Terlarut (DO) Dan Kebutuhan Oksigen Biologi (BOD) Sebagai Salah Satu Indikator Untuk Menentukan Kualitas Perairan. Oseana, Volume XXX, Nomor 3, p. $21-26$ (2005)

12. Sutimin, Model Matematika Konsentrasi Oksigen Terlarut Pada Ekosistem Perairan Danau. Jurusan Matematika, FMIPA, Universitas Diponegoro, Semarang (2006)

13. Peraturan Pemerintah No. 82. Pengelolaan Kualitas Air dan Pengendalian Pencemaran Air (2001) 